Gut, 1972, 13, 88-94

\title{
The detection and measurement of circulating gastrin-like activity by bioassay
}

\author{
D. G. COLIN-JONES ${ }^{1}$ AND J. E. LENNARD-JONES
}

From the Departments of Gastroenterology and Surgery, University College Hospital Medical School, London

SUMMARY A perfused rat stomach technique which can detect synthetic human gastrin I in amounts greater than $10 \mathrm{ng}$ and measure by block assay amounts greater than $50 \mathrm{ng}$ was used to study circulating gastrin-like activity in normal subjects, patients with peptic ulcer, and patients with the Zollinger-Ellison syndrome. No detectable activity was found in normal subjects or patients with gastric ulcer before or after meals. No activity was found in the fasting plasma of patients with duodenal ulcer but after meals activity could be detected in duplicate samples in seven of 20 patients. In nine proven cases of the Zollinger-Ellison syndrome, gastrin-like activity in the plasma ranged from 15 to $356 \mathrm{ng} / \mathrm{ml}$. The gastrin-like content of two tumours was 6.4 and $29.1 \mu \mathrm{g} / \mathrm{g}$ of tissue. The significance of these findings in relation to immunoassay is described.

A bioassay has been used as a test in several centres to detect circulating gastric secretagogue activity in patients with the Zollinger-Ellison syndrome (Moore, Murat, Endahl, Baker, and Zollinger, 1967; Wilson, Mathison, Schulte, and Ellison, 1968; Thomson, Cleator, and Sircus, 1970). However, only one measurement by bioassay of circulating gastrin-like activity in a patient with the syndrome has been reported (Colin-Jones, Gibbs, Copping, and Sharr, 1969).

Recently specific immunoassays have been developed (McGuigan, 1968) and raised levels of circulating gastrin have been found in the ZollingerEllison syndrome (Trudeau and McGuigan, 1969; Yalow and Berson, 1970). However, although immunoassay is highly specific, bioassay is also required to show that what is immunologically reactive is physiologically active and to detect secretagogues other than gastrin. This paper reports observations using bioassay on circulating gastrin-like activity in normal subjects, patients with peptic ulcer, and nine patients with the Zollinger-Ellison syndrome.

\section{Methods}

PERFUSED RAT STOMACH

The technique of estimating gastrin-like activity was

Received for publication 2 November 1971.

${ }^{1}$ In receipt of a grant from the Medical Research Council. Present address: Southampton General Hospital, Southampton. developed from the original method of Ghosh and Schild (1958) and has been reported elsewhere (Smith, Lawrence, Colin-Jones, and Schild, 1970). The stomach of a rat anaesthetized with urethane is continuously perfused with a dilute succinicpropionic buffer which gives a virtually linear change of $p \mathrm{H}$ with added $\mathrm{H}^{+}$over the $p \mathrm{H}$ range used $(4 \cdot 6-5 \cdot 6)$. The fluid is continuously recirculated so that hydrogen ions accumulate which enable very small changes in $p \mathrm{H}$ to be detected by the $p \mathrm{H}$ electrode. Knowing the volume and concentration $(\mathrm{M} / 600)$ of the buffer, the hydrogen ions secreted can be calculated.

DOSE RESPONSE CURVE

Using a $7 \times 7$ Latin square assay a dose response curve to human gastrin I was obtained and has been published elsewhere (Smith et al, 1970). The minimum reliably detectable dose was 10 nanograms given as a single intravenous dose and the steepest part of the dose response curve was 50-200 nanograms.

THE POTENCY OF GASTRIN ADDED TO PLASMA A comparison was made between synthetic human gastrin I injected in saline $(1.0 \mathrm{ml})$ to the same doses (50 and $150 \mathrm{ng}$ ) given in $1.0 \mathrm{ml}$ of fasting plasma. Using a formal assay, the potency ratio, saline gastrin/plasma gastrin, was 1.18 with $95 \%$ confidence limits of 0.92 and 1.55. An analysis of variance table (Table I) is presented which shows no significant differences between the saline and plasma gastrins 


\begin{tabular}{|c|c|c|c|c|}
\hline Source of Variation & Degrees of Freedom & Sum of Squares & Mean Square & $\boldsymbol{P}$ \\
\hline $\begin{array}{l}\text { Linear regression } \\
\text { Deviation from parallelism } \\
\text { Between saline and plasma } \\
\text { Between the four rats } \\
\text { Between the order of doses } \\
\text { Error }\end{array}$ & $\begin{array}{l}1 \\
1 \\
1 \\
3 \\
3\end{array}$ & $\begin{array}{r}219 \cdot 114 \\
0 \cdot 082 \\
5 \cdot 073 \\
31 \cdot 904 \\
11 \cdot 243 \\
11 \cdot 510\end{array}$ & $\begin{array}{r}219 \cdot 114 \\
0.082 \\
5 \cdot 073 \\
10 \cdot 634 \\
3 \cdot 747 \\
1 \cdot 918\end{array}$ & $\begin{array}{l}\ll 0.001 \\
>0.2 \\
=02-01 \\
<0.05 \\
>0.2\end{array}$ \\
\hline Total & 15 & 278928 & & \\
\hline
\end{tabular}

Table I Analysis of variance for $2 \times 2$ assay of gastrin in plasma and saline (50 and $150 \mathrm{ng}$ )

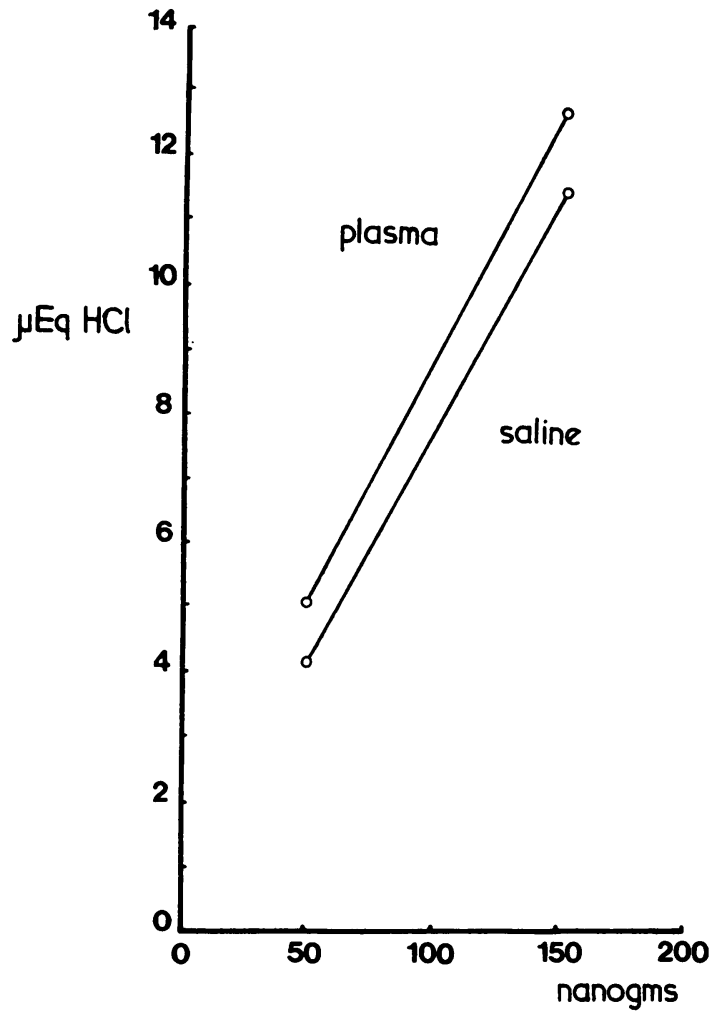

Fig. 1 Dose response for synthetic human gastrin I in plasma and saline.

which gave parallel responses (Fig. 1). These results enabled gastrin given in saline to be compared directly with plasma samples.

MEASUREMENT OF GASTRIN-LIKE ACTIVITY By using four animals concurrently a formal $2 \times 2$ block assay can be done with confidence limits of $\pm 30 \%$ but to do this the gastrin levels must lie on the steep part of the dose response curve (50-200 $\mathrm{ng}$ ) and relatively large volumes of material must be available for testing. It was possible to measure in

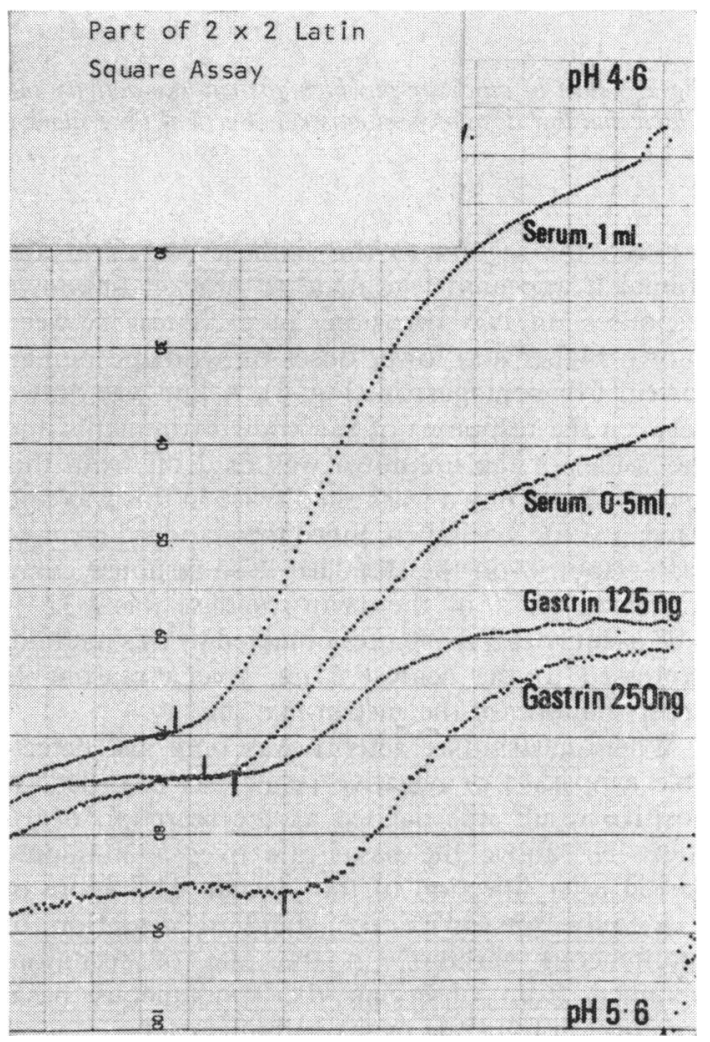

Fig. 2 A photograph of part of an assay on the serum from patient 1 , showing the change in $\mathrm{pH}$ of the buffer in response to gastrin and plasma. Each test line represents the response by one rat. Vertical lines mark intervals of five minutes.

this way levels of gastrin-like activity in the plasma (Fig. 2) in a secondary tumour from one patient and in a primary tumour from another patient.

Unfortunately, the samples of plasma examined usually contained too little gastrin-like activity or were too small in volume for a block assay. Since analysis of variance showed no significant variations 


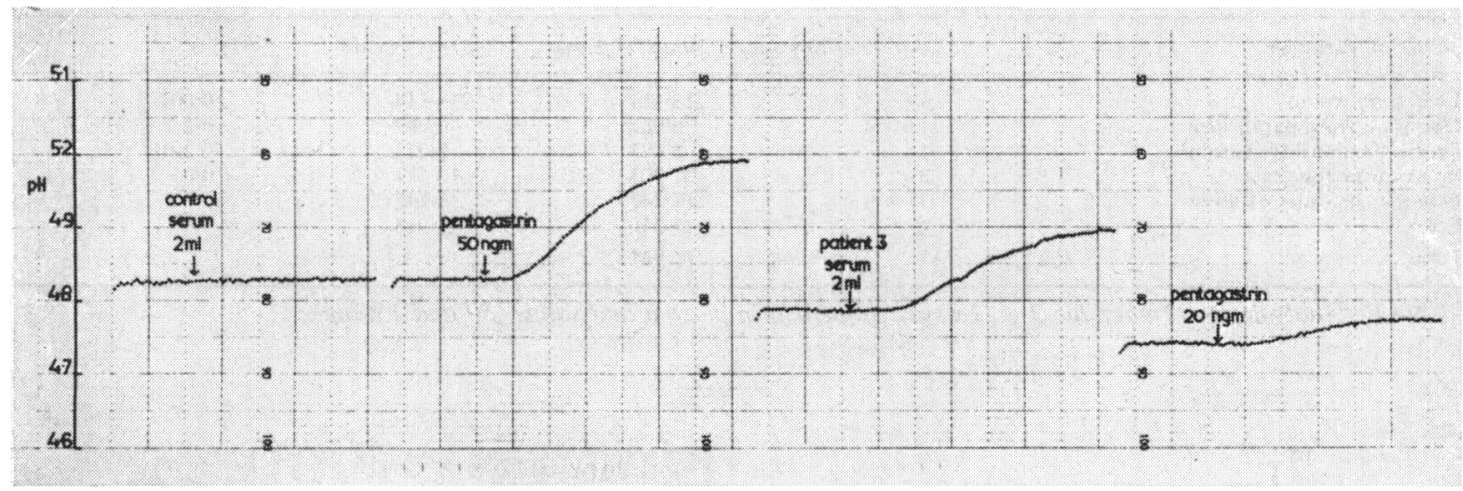

Fig. 3 Part of an assay in which gastrin-like activity in plasma from patient 3 was estimated by bracketing between a high and low dose of pentagastrin. Vertical lines mark intervals of five minutes.

between the second to the sixth responses in any animal it appeared legitimate to bracket unknown responses on two occasions in each test between known higher and lower doses of synthetic human gastrin I or pentagastrin (Fig. 3). A line was drawn between the responses of the known stimulants and the value for the unknown was read off from this line. Each unknown was tested twice in this way and a mean value was taken. Since the standard error of each response on the standard dose response curve was small (at $20 \mathrm{ng}$ the mean response was $2 \cdot 32 \pm$ $0.08 \mu$-equiv $\mathrm{H}^{+}$) the figures obtained by this method, expressed to the nearest $5 \mathrm{ng}$, give a reasonable approximation of the gastrin-like activity.

Where gastrin-like activity was only just detectable a positive or negative result was recorded. A positive result was defined as the secretion of $1 \mu$ equiv $\mathrm{H}^{+}$above the basal rate over a 30 -minute period after injection of the plasma. The figure of $1 \mu$-equiv was twice the standard deviation of spontaneous variation in the rate of secretion, obtained from observing the spontaneous basal secretion in four rats over two hours each.

\section{SAMPLES}

Plasma was obtained from all patients after an eight-hour fast. In some patients further samples were taken at intervals after the start of an appetizing high protein meal. The plasma was rapidly spun down and if not tested that day was stored at $-20^{\circ} \mathrm{C}$. When deep frozen, the plasma was thawed at less than $37^{\circ}$ and briefly centrifuged before intravenous injection.

\section{ROUTINE}

As Lai (1964) also observed, the first injection after preparation of the rats gave an unreliable result; the second dose of stimulant, either synthetic human gastrin I or Pentagastrin (ICI), 50 ng, was used as a standard and only those animals that responded well were used to assay plasma. It has been shown by formal assay that $50 \mathrm{ng}$ of Pentagastrin and human gastrin I give similar responses (Smith et al, 1970). The plasma $(2.0 \mathrm{ml})$ was injected steadily over a measured period of 90 to 120 seconds. A temporary change in respiratory rate was invariably observed but severe adverse effects rarely occurred, contrary to the experience of Thomson et al (1970). One hour after the plasma, a further standard was given to bracket the unknown and to ensure that the rat was still responsive. The procedure was repeated with hourly injections of gastrin or plasma. The responsiveness of the rat usually deteriorated after two injections of plasma.

\section{Results}

NORMAL SUBJECTS

Plasma was taken from 10 normal male subjects (aged 21-34) while fasting, and 30 and 60 minutes after the start of a meal. No secretory response was observed in any of the fasting samples or in eight of the 10 postprandial samples. In two subjects the half-hour sample gave one positive and one negative response, suggesting that gastrin-like activity was, perhaps, just detectable.

PATIENTS WITH GASTRIC ULCER No gastrin-like activity was detectable in the plasma of three patients with gastric ulcer before or after a meal.

PATIENTS WITH DUODENAL ULCER

Plasma was studied from 20 patients with proven 


\begin{tabular}{|c|c|c|c|c|c|c|}
\hline \multicolumn{7}{|c|}{ Result of One of Duplicate Tests } \\
\hline \multirow{3}{*}{$\frac{\text { Patient }}{1}$} & \multicolumn{2}{|c|}{ Fasting } & \multicolumn{2}{|c|}{ Half Hour } & \multicolumn{2}{|c|}{ One Hour } \\
\hline & - & - & + & + & + & - \\
\hline & - & & $*$ & - & - & - \\
\hline 3 & - & - & - & - & - & + \\
\hline 4 & - & & + & + & * & - \\
\hline 5 & - & & + & - & - & + \\
\hline 6 & - & - & - & - & + & + \\
\hline 7 & - & - & + & + & + & + \\
\hline 8 & - & & + & - & - & - \\
\hline 9 & - & - & + & $*$ & + & - \\
\hline 10 & - & & + & - & - & - \\
\hline 11 & - & & - & - & + & - \\
\hline 12 & - & - & + & - & + & + \\
\hline 13 & - & - & + & - & + & - \\
\hline 14 & - & - & - & + & + & + \\
\hline 15 & - & - & + & + & + & + \\
\hline 16 & - & & + & - & - & - \\
\hline 17 & - & - & + & $*$ & - & + \\
\hline 18 & - & - & + & - & - & - \\
\hline 19 & - & & - & - & - & + \\
\hline 20 & - & - & - & - & - & - \\
\hline
\end{tabular}

Table II Detection of gastrin-like activity in duodenal ulcer patients after a meal ${ }^{1}$

${ }^{1}$ Each symbol represents the result of one of the duplicate tests. $+=$ positive result, $-=$ negative result, ${ }^{*}=$ unreliable result

duodenal ulcers who were experiencing symptoms at the time of investigation. No gastrin-like activity was detected while the patients were fasting but a positive response (Table II) in duplicate samples was obtained from seven patients tested at half an hour or one hour after the meal; a positive response was obtained in one or more of the samples tested after the meal in 18 of the 20 patients. Variation in responsiveness of the animals to low doses of gastrin accounts for the poor concordance between duplicate results. It can be seen from Table II that seven of the 20 patients showed consistent responses at 30 or 60 minutes and this is significantly different from the controls $\left(\chi^{2}=4 \cdot 47, \mathrm{P}<0.05\right)$.

PATIENTS WITH THE ZOLLINGER-ELLISON SYNDROME (TABLE III)

\section{Known tumour tissue present}

Seven patients were studied and brief clinical details and the results of the assays are set out in Table II. Full details of the patients have been reported elsewhere (Colin-Jones, 1971). Observations on circulating gastrin-like activity in one of the patients have been reported elsewhere (Colin-Jones et al, 1969). In patient 7 , the plasma was taken while the patient was bleeding; it proved toxic to the animals and no reproducible result was obtained.

Patients with the Zollinger-Ellison syndrome after removal of tumour tissue

No circulating gastrin-like activity was found in these two patients (cases 8 and 9).
PATIENTS SUSPECTED OF HAVING THE ZOLLINGER-ELLISON SYNDROME

Negative results

Twenty-eight patients had fasting plasma examined for gastrin-like activity with negative results; plasma from one other patient gave equivocal results with a positive result in some animals but not in others. The subsequent clinical course of these 29 patients has not supported the diagnosis of ZollingerEllison syndrome.

\section{Positive results}

Fasting gastrin levels of 15 to $20 \mathrm{ng} / \mathrm{ml}$ were found in two patients who probably had the ZollingerEllison syndrome but in whom the diagnosis was not proven. The first patient had steatorrhoea, gastric hypersecretion, dyspepsia, and hyperparathyroidism but no laparotomy has, as yet, been performed. The second patient had recurrent peptic ulceration, gastric hypersecretion, with a gastric, duodenal, and jejunal ulcer at various times, but no tumour was found in a partial pancreatectomy specimen.

\section{Discussion}

The present experiments were an attempt to quantify the gastrin-like activity in blood by a bioassay method. The modifications applied to the original Ghosh and Schild (1956) method appear to increase sensitivity and reproducibility and allow measurements of gastrin-like activity to be made with acceptable confidence limits. However, despite these improvements, the technique was only capable of detecting $10 \mathrm{ng}$ and was unable to measure accurately levels below $50 \mathrm{ng}$. In the range of 5 to $20 \mathrm{ng} / \mathrm{ml}$ plasma the method lacked reproducibility as shown by the study in the peptic ulcer subjects. A further problem is that the bioassay is not specific for gastrin, though the rat is relatively insensitive to histamine and responds only to doses greater than $10 \mu \mathrm{g}$ in the preparation used here.

Levels of circulating gastrin are too low for measurement by the perfused rat stomach technique in normal subjects or patients with duodenal ulcer. Detectable levels of circulating gastric secretagogue after a meal have been found by this method in seven of 20 patients with duodenal ulcer, but no activity was demonstrable in normal subjects. Herring and Blair (1969) found elevated levels of fasting gastrinlike activity in duodenal ulcer patients using their anaesthetized cat preparation, and Byrnes, Young, Chisholm, and Lazarus (1970) confirmed this using their immunoassay with an antibody to the C-terminal pentapeptide. However, in contrast to 


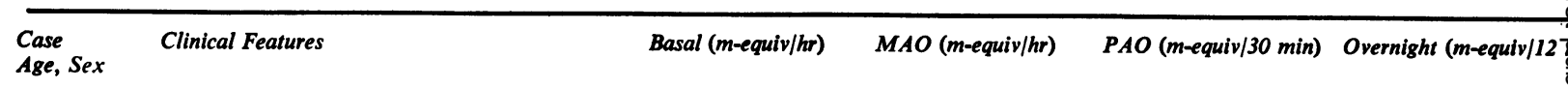

\begin{tabular}{|c|c|c|c|c|}
\hline $\begin{array}{l}1 \\
73, F\end{array}$ & $\begin{array}{l}\text { Diarrhoea, gastric ulcer, gastrointestinal } \\
\text { bleed, skin nodules, died carcinomatosis (full } \\
\text { details reported by Colin-Jones et al, 1969) }\end{array}$ & 5 & $25 \cdot 8$ & 166 \\
\hline
\end{tabular}

\begin{tabular}{|c|c|c|c|c|c|}
\hline $\begin{array}{l}2 \\
52, F\end{array}$ & $\begin{array}{l}\text { Diarrhoea, abdominal pain, large ulcers } 1 \text { st } \\
\text { and } 4 \text { th parts duodenum, partial gastrectomy } \\
\text { and removal of nodule under duodenal mucosa; } \\
\text { well } 1 \text { year later }\end{array}$ & $29 \cdot 2$ & & 40.4 & \\
\hline $\begin{array}{l}3^{3} \\
54, M\end{array}$ & $\begin{array}{l}\text { Diarrhoea, hyperparathyroidism, parathyroid } \\
\text { adenoma removed, gastrointestinal bleed, } \\
\text { pancreatic nodules, near-total gastrectomy; } \\
\text { died from acute cholecystitis } 3 \text { years later, } \\
\text { residual tumour present }\end{array}$ & 23 & & 58 & \\
\hline $\begin{array}{l}4 \\
45, M\end{array}$ & $\begin{array}{l}\text { Dyspepsia, pyloric stenosis, partial gastrec- } \\
\text { tomy, stomal ulcer, vagotomy, further stomal } \\
\text { ulcer, high partial gastrectomy, recurrent pain, } \\
\text { total gastrectomy, oesophageal stricture: well } \\
3 \text { years after total gastrectomy }\end{array}$ & & & & \\
\hline $\begin{array}{l}5 \\
56, F\end{array}$ & $\begin{array}{l}\text { Abdominal pain, diarrhoea, duodenal ulcer, } \\
\text { steatorrhoea, pancreatic tumour; died } \\
\text { carcinomatosis }\end{array}$ & 29.5 & & 145 & \\
\hline $\begin{array}{l}6 \\
55, M\end{array}$ & $\begin{array}{l}\text { Dyspepsia, gastrointestinal bleeds, oesophageal } \\
\text { ulcer and stricture, duodenal ulcer after } \\
\text { vagotomy and pyloroplasty, total gastrectomy; } \\
\text { well after } 1 \text { year }\end{array}$ & $20 \cdot 7$ & $84 \cdot 5$ & & $\begin{array}{l}240 \\
\text { (10 hour) }\end{array}$ \\
\hline $\begin{array}{l}7 \\
67, F\end{array}$ & $\begin{array}{l}\text { Dyspepsia, gastrointestinal bleeds, large ulcers } \\
\text { in first, second, and third parts of duodenum, } \\
\text { pancreatic tumour, total gastrectomy; died } \\
\text { postoperatively }\end{array}$ & 55 & 78 & & \\
\hline $\begin{array}{l}8 \\
44, M\end{array}$ & $\begin{array}{l}\text { Malignant insulinoma, steatorrhoea, } \\
\text { hyperparathyroidism, total pancreatectomy, } \\
\text { three of four hyperplastic parathyroids } \\
\text { removed; well } 4 \text { years after pancreatectomy }\end{array}$ & 20.5 & & 66 & \\
\hline $\begin{array}{l}9 \\
40, F\end{array}$ & $\begin{array}{l}\text { Hyperparathyroidism, parathyroid adenomas } \\
\text { removed, diarrhoea, duodenal ulcer, total } \\
\text { gastrectomy; well } 3 \text { years later }\end{array}$ & 32 & $27 \cdot 6$ & & 159 \\
\hline
\end{tabular}

Table III Results in patients with the Zollinger-Ellison syndrome

their results, work with the immunoassay using an antibody to the heptadecapeptide gastrin has shown little difference in the fasting levels of gastrin between patients with duodenal ulcer and normal subjects, all levels being less than $400 \mathrm{pg} / \mathrm{ml}$ (Hansky and Cain, 1969; Trudeau and McGuigan, 1970) and the highest value so far noted after an appetizing protein meal in normal subjects and patients with peptic ulcer was about $600 \mathrm{pg} / \mathrm{ml}$ (Walsh, Yalow, and Berson, 1971; Korman, Soveny, and Hansky, 1971), a level well below that detectable by the bioassay described here.

Although too insensitive for the measurement of physiological gastrin levels, this bioassay technique has proved useful in the diagnosis of the Zollinger-
Ellison syndrome. It has been used to measure circulating gastrin-like levels with reasonable confidence limits in one patient (case 1) and approximate measurements have been made in six other confirmed cases (cases 2-7). The levels of 324 to $356 \mathrm{ng} / \mathrm{ml}$ recorded in case 1 are higher than those usually found by immunoassay in patients with the ZollingerEllison syndrome, perhaps due to the large bulk of secreting tumour tissue in a diminutive woman. Levels of gastrin-like activity in the other patients studied ranged from 15 to $50 \mathrm{ng} / \mathrm{ml}$ (Table JI) which fall within the levels of 0.6 to $300 \mathrm{ng} / \mathrm{ml}$ found by immunoassay (McGuigan, 1970).

Recently, a total gastrectomy has been shown to cause tumour regression (Friesen, 1968) and follow up 


\begin{tabular}{|c|c|c|c|c|}
\hline \multirow[t]{3}{*}{ Pathology } & \multicolumn{4}{|c|}{ Gastrin-like Activity } \\
\hline & \multicolumn{3}{|c|}{ Plasma (ng/ml approximate or $+95 \%$ confidence units) } & \multirow[t]{2}{*}{ Tumour Extract $(\mu g / g)$} \\
\hline & Fasting & Postprandial & Postoperative & \\
\hline $\begin{array}{l}\text { Non } \beta \text {-islet cell carcinoma of pancreas, } \\
\text { metastases in spleen, lymph nodes, and skin }\end{array}$ & $\begin{array}{l}324 \\
(-32 \%+86 \%)\end{array}$ & $\begin{array}{l}336(1 \text { hour }) \\
(-28 \%+66 \%) \\
356(2 \mathrm{hr}) \\
(-16 \%+24 \%)\end{array}$ & & $\begin{array}{l}6 \cdot 4^{2} \\
(-27 \%+29 \%)\end{array}$ \\
\hline $\begin{array}{l}\text { Nodule first part of duodenum, non } \beta \text {-islet } \\
\text { cell tumour, ? malignant }\end{array}$ & 15 & $\begin{array}{l}15(30 \mathrm{~min}) \\
15(1 \mathrm{hr})\end{array}$ & Nil & $\begin{array}{l}29 \cdot 1^{2} \\
(-21 \%+28 \%)\end{array}$ \\
\hline $\begin{array}{l}\text { Multiple non } \beta \text {-islet cell adenomas of } \\
\text { pancreas }\end{array}$ & $\begin{array}{l}20(1968) \\
25(1969)\end{array}$ & $\begin{array}{l}30(1 \mathrm{hr}) \\
25(2 \mathrm{hr})\end{array}$ & & \\
\hline $\begin{array}{l}\text { Nodules in duodenum. Histology? } \\
\text { carcinoid }\end{array}$ & 40 & $\begin{array}{l}50(30 \mathrm{~min}) \\
40(1 \mathrm{hr}) \\
70(90 \mathrm{~min}) \\
40(2 \mathrm{hr})\end{array}$ & & \\
\hline $\begin{array}{l}\text { Non } \beta \text {-islet cell carcinoma of pancreas with } \\
\text { liver metastases }\end{array}$ & 25 & & & \\
\hline $\begin{array}{l}\text { Mass in pancreas with several nodules; no } \\
\text { biopsy taken }\end{array}$ & $15-20$ & $\begin{array}{l}15-20(30 \mathrm{~min}) \\
(15-20(1 \mathrm{hr})\end{array}$ & & \\
\hline Islet cell carcinoma of pancreas & $\begin{array}{l}\text { Plasma toxic to a } \\
\text { doubtful results }\end{array}$ & & & \\
\hline Malignant islet cell carcinoma of pancreas & & & Nil & $\begin{array}{l}\text { Gastrin-like activity found } \\
\text { by R. A. Gregory }\end{array}$ \\
\hline $\begin{array}{l}\text { Non } \beta \text {-islet cell tumour of pancreas with } \\
\text { lymph node metastasis }\end{array}$ & & & Nil & \\
\hline
\end{tabular}

Table III Results in patients with the Zollinger-Ellison syndrome-continued

${ }^{2}$ Extracted by the method of Grossman, Tracy, and Gregory (1961)

Extracted by the first stage of the method of Gregory and Tracy (1964) with the addition of homogenization and extraction twice with DEAE cellulose.

has shown a reduction in circulating gastrin levels (Passaro, Basso, Sanchez, and Gordon, 1970). Of interest, therefore, is case 4 in whom a high circulating gastrin-like level persisted despite total gastrectomy.

The assay of gastrin is of value in following proven cases to detect early signs of tumour recurrence. The negative results in case 8 suggests removal of gastrin-secreting tissue although insulin-secreting tumour is known to remain.

The gastrin content of two tumours was found to be $6.4 \mu \mathrm{g}$ and $29.1 \mu \mathrm{g} / \mathrm{g}$ of tumour tissue, which compares well with the level of $1.03 \mu \mathrm{g} / \mathrm{g}$ found by McGuigan and Trudeau (1968) using immunoassay but not with the level of $1.07 \mathrm{mg} / \mathrm{g}$ tentatively suggested by Thompson, Hirose, Lemmi, and Davidson (1968). The latter workers used the isolated bullfrog mucosa to compare the maximal responses of the membrane to gastrin and tumour extract. These results compare with a mean of $4.6 \mu \mathrm{g}$ of gastrin-like activity/g of human antral tissue in personal studies (Colin-Jones, 1971) using the extraction method of Gregory and Tracy (1964).

All but one of the patients with the ZollingerEllison syndrome reported here in whom tumour tissue was present had a detectable circulating gastric secretagogue and Moore et al (1967) and Thomson et al (1970) found similar results. However, neither of these two groups of workers attempted to measure the levels of circulating gastrin. Wilson et al 
(1968) detected only 10 out of 25 proven cases of the Zollinger-Ellison syndrome with their technique which appears to correlate better with the levels found by immunoassay because the lower levels of circulating gastrin, 0.6-10 ng/ml, measured in such patients by immunoassay, would be undetectable by bioassay, whereas only the higher levels 10 to $300 \mathrm{ng}$ (McGuigan, 1970) would be detectable by both methods. Further studies are clearly required to investigate these findings more fully.

We are grateful to Professor H. O. Schild and Professor C. G. Clark for laboratory facilities. We thank those who referred us cases especially Sir Francis Avery Jones, Mr L. Collis, Dr D. Gibbs, Mr P. W. Ingram, Dr M. Langman, Dr C. Mallison, Dr S. Rune, Mr F. Tovey, and Professor R. Welbourn.

Requests for reprints should be sent to J.E.L-J., University College Hosfital, Gower Street, London, WC1E 6AU.

References

Byrnes, D. J., Young, J. D., Chisholm, D. J., and Lazarus, L. (1970). Serum gastrin in patients with peptic ulceration. Brit. med. J., 2, 626-629.

Colin-Jones, D. G., Gibbs, D. D., Copping, R. M. L., and Sharr, M. M. (1969). Malignant Zollinger-Ellison syndrome with gastrin containing skin metastases. Lancet, 1, 492-494.

Colin-Jones, D. G. (1971). The detection and bioassay of gastrin by its effect on gastric secretion. MD Thesis, University of London.

Friesen, S. R. (1968). A gastric factor in the pathogenesis of the Zollinger-Ellison syndrome. Ann. Surg., 168, 483-501.

Ghosh, M. N., and Schild, H. O. (1958). Continuous recording of acid gastric secretion in the rat. Brit. J. Pharmacol., 13, 54-61.

Gregory, R. A., and Tracy, J. H. (1964). The constitution and properties of two gastrins extracted from hog antral mucosa. Gut, 5 , 103-117.
Grossman, M. I., Tracy, H., J. and Gregory, R. A. (1961). ZollingerEllison syndrome in a Bantu woman with isolation of a gastrin-like substance from the primary and secondary tumors. II. Extraction of gastrin-like activity from tumors. Gastroenterology, 41, 87-91.

Hansky, J., and Cain, M. D. (1969). Radioimmunoassay of gastrin in human serum. Lancet, 2, 1388-1390.

Herring, D. W., and Blair, E. L. (1969). Gastrin activity in the plasma of normal subjects and patients with duodenal ulceration. Brit. J. Surg., 56, 707-708.

Ingram, P. W. (1964). Multiple adenoma syndrome. Proc. roy. Soc. Med., 57, 1126-1127.

Korman, M. G., Soveny, C., and Hansky, J. (1971). Effect of food on serum gastrin evaluated by radioimmunoassay. Gut, 12, 619-624.

Lai, K. S. (1964). Studies on gastrin. Gut, 5, 327-341.

McGuigan, J. E. (1968). Immunochemical studies with synthetic human gastrin. Gastroenterology, 54, 1005-1011.

McGuigan, J. E. (1970). Immunologic studies of gastrin. New Engl. J. Med., 283, 137-142.

Moore, F. T., Murat, J. E., Endahl, G. L., Baker, J. L., and Zollinger, R. M. (1967). Diagnosis of ulcerogenic tumor of the pancreas by bioassay. Amer. J. Surg., 113, 735-737.

Passaro, E., Jr., Basso, N., Sanchez, R. E., and Gordon, H. E. (1970). New studies in the Zollinger-Ellison syndrome. Amer. J. Surg., 120, 138-143.

Smith, G. M., Lawrence, A. J., Colin-Jones, D. G., and Schild, H. O. (1970). The assay of gastrin using the perfused rat stomach. Brit. J. Pharmacol., 38, 206-213.

Thompson, J. C., Hirose, F. M., Lemmi, C. A. E., and Davidson, W. D. (1968). Zollinger-Ellison syndrome in a patient with multiple carcinoid islet cell tumors of the duodenum. Amer. J. Surg., 115, 177-184.

Thomson, C. G., Cleator, I. G. M., and Sircus, W. (1970). Experiences with a rat bio-assay in the diagnosis of the Zollinger-Ellison syndrome. Gut, 11, 409-419.

Trudeau, W. L., and McGuigan, J. E. (1969). Effects of calcium on serum igastrin levels in the Zollinger-Ellison syndrome. New Engl. J. Med., 281, 862-866.

Trudeau, W. L., and McGuigan, J. E. (1970). Serum gastrin levels in patients with peptic ulcer disease. Gastroenterology, 59, 6-12.

Walsh, J. H., Yalow, R. S., and Berson, S. A. (1971). The effect of atropine on plasma gastrin response to feeding. Gastroenterology, 60, 16-21.

Wilson, S. D., Mathison, J. A., Schulte, W. J., and Ellison, E. H. (1968). The role of bioassay in the diagnosis of ulcerogenic tumors. Arch. Surg., 97, 437-443.

Yalow, R. S., and Berson, S. A. (1970). Radioimmunoassay of gastrin. Gastroenterology, 58, 1-14. 